\title{
Effect of Precision Land Levelling, Zero Tillage and Residue Management on Yield and Water Productivity of Wheat (Triticum aertivum L.) under Saline Vertisols of Tungabhadra Project Command
}

\author{
R.H. Rajkumar ${ }^{1 *}$, A.T. Dandekar ${ }^{2}$, S.R. Anand ${ }^{3}$, J. Vishwantha ${ }^{4}$, A.V. Karegoudar ${ }^{4}$, \\ P.H. Kuchnur ${ }^{5}$ and Yogesh Kumar Singh ${ }^{6}$
}

\author{
${ }^{1}$ Directorate of Research, UAS, Raichur, Karnataka, India \\ ${ }^{2}$ College of Agricultural Engineering, Raichur-584 104, Karnataka, India \\ ${ }^{3}$ AICRP on Potential crops, UAS, GKVK, - Bangalore, Karnataka, India \\ ${ }^{4}$ AICRP on Management of Salt Affected Soils and Use of Saline Water in Agriculture, \\ Agricultural Research Station, Gangavathi-583 227, Karnataka, India \\ ${ }^{5}$ College of Agriculture Bheemarayangudi, Karnataka, India \\ ${ }^{6}$ CIMMYT New Delhi, India
}

*Corresponding author

\section{Keywords}

Saline vertisols, Laser leveling, Zero tillage, Water saving, Soil organic carbon

Article Info

Accepted: 20 September 2018 Available Online: 10 October 2018
A B S T R A C T

A field experiment was carried out at Agricultural Research Station, Gangavathi, Karnataka during 2012-13 to 2014-15 A comparison of Laser guided leveler technology with zero tillage along with crop residue treatment and Farmers practice were carried out and it was found that Significantly higher yield and straw was recorded in the former practice ( 2450 and $2756 \mathrm{~kg} \mathrm{ha}^{-1}$ ) as compared to later (1850 and $1950 \mathrm{~kg} \mathrm{ha}^{-1}$ ). Similarly, number of plants per sq. meter area and plant height was significantly higher in laser leveling with zero tillage and 100\% previous crop residue retained treatment and lowest in normal leveled land in farmers practice. Among eight treatment, the quantum of irrigation water applied was less in case of laser leveling with zero tillage with $100 \%$ previous crop residue retained treatment followed by laser leveling with zero tillage with 50\% previous crop residue retained treatment and was more in case of farmers practice (control). The total water saving was to the extent of $27 \%$ in case of laser leveling with zero tillage with $100 \%$ crop residue retained treatment over control treatment. After harvest, the $\mathrm{pH}$ and ECe of the blocks varied between 7.9-8.66 and 4.04$9.04 \mathrm{dS} / \mathrm{m}$ at $0-15 \mathrm{~cm}$ and $7.87-8.68$ and $3.76-8.25 \mathrm{dS} / \mathrm{m}$ at $15-30 \mathrm{~cm}$ depths respectively. After harvest of third year crop, slightly higher soil organic carbon content was recorded at surface depth $(0-15 \mathrm{~cm})$ in $\mathrm{T}_{7}$ treatment as compared to before sowing. It was concluded that, higher yield of wheat and water saving can be achieved in laser leveled land by using $100 \%$ previous crop residue retained in zero till land under saline soils. 


\section{Introduction}

Wheat (Triticum aertivum L.) is one of the most important winter cereal in India, contributing approximately $30-36 \%$ of total food grain production of the country having cultivated land of $29.8 \mathrm{~m}$ ha with a total production of $93.9 \mathrm{~m} \mathrm{t}$ and productivity of $3140 \mathrm{~kg} \mathrm{ha}^{-1}$ (FAOSTAT and IGC, 2011-12). However, the world average yield is $3257 \mathrm{~kg}$ $\mathrm{ha}^{-1}$ this loss yield could be minimized through manipulation of tillage operations enables early sowing of wheat by adopting the concept of Resource Conservation Technologies (RCTs).

RCTs such as precision land leveling (laser guided land leveling), zero-tillage (ZT) and bed planting have been shown to be beneficial in terms of improving soil health, water use, crop productivity and farmers' income (Gupta and Sayre, 2007; Gupta and Seth, 2007). Precision land leveling is known to enhance water-use efficiency and consequently water productivity. Conventional surface irrigation practices in unleveled lands normally result in over irrigation (Corey and Clyma, 1973). Laser-assisted precision land leveling (PLL) considered as a precursor technology for RCTs have been reported to improve crop yield and input-use efficiency including water and nutrients (Jat et al., 2006a). This also results in saving of excessive loss of irrigation water through deep percolation and increases the application efficiency up to 25\% (Sattar et al., 2003). PLL helps even distribution of soluble salts in salt-affected soils (Khan, 1986), increases cultivable land area up to 3$5 \%$ (Choudhary et al., 2002; Jat and Chandana, 2004), improves crop establishment, reduces weed intensity (Rickman, 2002) and results in saving of irrigation water (Jat et al., 2003; Khattak et al., 1981). PLL has been shown to improve water management and it saves up to $50 \%$ of irrigation water (Rickman, 2002; Jat et al., 2006a). Other benefits of laser land leveling include improved crop stand and crop productivity (up to 30\%) and reduced labour requirement (Rickman et al., 1998; Jat et al., 2006a).

The soil environment with zero tillage (ZT) differs considerably from that of tilled soils. In general soils under no-tillage are wetter, have different temperature regimes and are more compact than those under conventional tillage (USDA, 1977). Zero tillage cultivation accelerates oxidation of organic matter by soil micro-organisms through change in soil water relationship, aeration and temperature regimes and nutritional environment (Doran and Smith, 1987). In wheat, ZT reduces irrigation requirements compared with conventionaltillage by using residual water more effectively (Gupta et al., 2003; Erenstein et al., 2007). It has been proved that ZT could save $\$ 40-50 \mathrm{ha}^{-1}$ input cost, $13-33 \%$ water use and $75 \%$ fuel consumption (Malik et al., 2002).

The use of zero tillage system can also substantially reduce the lag period just after harvest of rice in rice - wheat system and wheat can be planted timely even with residual soil moisture, if rice is harvested 1015 days after irrigation. Delayed in wheat sowing beyond November reduces grain yield by $140-150 \mathrm{~kg} \mathrm{ha}^{-1}$ (Gill et al., 2008). The intensive tillage operations after the harvest of transplanted rice not only require a huge amount of energy and time but also increase the cost of production. To make system economically viable, it is essential to reduce the cost of input per unit. Under such situation, zero tillage in laser leveled land technology could be a valid option to reduce the turnaround time, cost and establishment of good plant stand of wheat without loss in productivity and sustainability of natural resources with increase in water production efficiency. 
In TBP project command area, farmers are burning the crop residue and they feel that burning is cost effective method of residue disposal however burning of residue causes pollution by releasing greenhouse gases and leading to global warming (Kirkby, 1999) and this is also leading to reduction in soil organic matter in many high productive zones of the command. Due to inequitable, inadequate and unreliable water supply to the farmers and late release of canal water to command area every year, tail end farmers are facing short supply of water and delay in planting of paddy in leading to lower yields. Excessive use of water by head reaches farmer than the other farmers of the command the downstream area of command suffering from waterlogging and salinity problem.

Further, taking up the second crop of paddy (summer) has become difficult due to nonavailability of water. Hence, the rice-wheat cropping technologies are becoming popular among farming community in the Tungabhadra project (TBP) command area in the last couple of years. Many studies were conducted on RCTs based single crop in ricewheat system but no attempt has been made to study the effect of combined RCTs (precision land leveling, zero tillage and residue management) in wheat under saline environment in command areas. The laser leveling and zero tillage concepts are very new to TBP command and there were no studies initiated till now. Therefore, this study was conducted to know the effect of precision land leveling, zero tillage and residue on wheat yield and water use efficiency under saline vertisols of TBP project command.

\section{Materials and Methods}

The experiment was conducted to know the effect of precision land leveling, zero tillage and residue on yield and water use efficiency of wheat in saline vertisols of TBP command area at Agricultural Research Station (A.R.S) Gangavathi of Koppal district, Karnataka state having latitude of $15^{\circ} 27^{\prime} 22.34$ " $\mathrm{N}$ and longitude of $76^{\circ} 31^{\prime} 54.59^{\prime \prime} \mathrm{E}$ during 2012-13 to 2014-15. The study area is situated in the north-eastern dry zone of the state (Altitude of $419 \mathrm{~m}$ above mean sea level) which is having average annual rainfall of $572 \mathrm{~mm}$. The average effective rainfall during the cropping season (October to March) was $149.1 \mathrm{~mm}$. The experiment was laid out in eight plots with an area of $0.06,0.06,0.05,0.06,0.08$, $0.08,0.11$ and 0.11 ha.

Before implementation of the experiment the initial slopes of the experiment site was measured and the slope ranges from 0.25 to 0.30 per cent and land was well prepared with two times tillering and one time rotovator for first sowing only. The experiment consisted of eight treatments viz., $\mathrm{T}_{1}$ - Control (Farmer's Practice), $\mathrm{T}_{2}$ - zero tillage with $100 \%$ previous crop residue retained, $\mathrm{T}_{3}$ - zero tillage in $100 \%$ previous crop residue removed, $\mathrm{T}_{4}$ - zero tillage with $50 \%$ previous crop residue retained, $\mathrm{T}_{5}$ - laser leveling with zero tillage and $100 \%$ previous crop residue retained, $\mathrm{T}_{6}-$ laser leveling with zero tillage and $50 \%$ previous crop residue retained, $\mathrm{T}_{7}$ - laser leveling with zero tillage and $100 \%$ previous crop residue removed and $\mathrm{T}_{8}$ - laser leveling with farmer's practice.

For determining the salt distribution in the soil profile, soil samples $(0-15$ and $15-30 \mathrm{~cm})$ were drawn and were analyzed using conductivity bridge in 1:2.5 soil water extract and $\mathrm{pH}$ of the soil were determined by using $\mathrm{pH}$ meter. The initial soil $\mathrm{pH}$ and ECe of the blocks varied between $8.19-8.85$ and $3.88-7.32 \mathrm{dS} / \mathrm{m}$ at $0-15$ $\mathrm{cm}$ and $8.16-8.93$ and $3.55-8.38 \mathrm{dS} / \mathrm{m}$ at $15-30$ $\mathrm{cm}$ depth respectively. The soil of the site was medium black clay in texture (clay, silt and sand in the proportion of 48.9, 29.0 and $22.1 \%$, respectively) having an infiltration rate of $5.5 \mathrm{~mm} / \mathrm{h}$. The mean bulk density and soil 
porosity of the experimental site ranged between 1.4 to $1.5 \mathrm{~g} / \mathrm{cc}$ and $42.2 \%$ to $47.1 \%$ respectively. The initial soil organic content ranged from 0.4 to $0.5 \%$.

The soil moisture was measured with gravimetric method for three times (Initial, 90 DAS (Days After Sowing) and at harvest). Laser leveling was done in different blocks as per the treatments $\left(T_{5}, T_{6}, T_{7}\right.$ and $\left.T_{8}\right)$. For the second season onwards the residue of harvested wheat was retained and sowing was done with the help of zero till seed cum fertilizer drill with inclined plate disc for the treatments of $\mathrm{T}_{2}, \mathrm{~T}_{3}, \mathrm{~T}_{4}, \mathrm{~T}_{5}, \mathrm{~T}_{6}$ and $\mathrm{T}_{7}$. The wheat was sown during Rabi with row spacing of $23 \mathrm{~cm}$ between two rows and for conventional tillage $\left(T_{1}, T_{8}\right)$ the traditional method of sowing with bullocks was followed with same spacing. For zero tillage treatments, the pre-emergent and post emergent sprayers were taken for the control of weeds and for conventional tillage methods the hand weeding was done. The quantum of irrigation water applied at each time for all the eight treatments were measured with cut-throat flume along with duration of irrigation. The applied irrigation depth was calculated by using the following equation:

$\mathrm{QT}=\mathrm{AD}(01)$

Where $\mathrm{Q}=$ Discharge (cubic metre $\left.\mathrm{h}^{-1}\right) ; \mathrm{T}=$ Time (h); $\mathrm{A}=$ Area (hectare), and D = Depth (mm).

The amount of water $\left(\mathrm{m}^{3}\right)$ applied to each treatment was determined by multiplying the discharge at field outlet with the time of application. The total amount of water applied was computed for the entire crop season for all the four treatments. Water productivity (WP) was computed as follow:

WP $\left(\mathrm{kg} \mathrm{m}^{-3}\right)=$ Yield $\left(\mathrm{kg} \mathrm{ha}^{-1}\right) /$ Total water applied $\left(\mathrm{m}^{3} \mathrm{ha}^{-1}\right)(02)$

\section{Results and Discussion}

\section{Yield and its attributes}

Pooled data of three years results revealed that significantly higher grain and straw yield was recorded in laser leveling with zero tillage and $100 \%$ previous crop residue retained treatment (2450 and $2756 \mathrm{~kg} \mathrm{ha}^{-1}$, respectively) which was on par with laser leveling with zero tillage and $50 \%$ previous crop residue retained treatment $\left(2340\right.$ and $2654 \mathrm{~kg} \mathrm{ha}{ }^{-1}$, respectively) as compared to other treatments and significantly lower yield (1850 kg ha $\left.{ }^{-1}\right)$ was recorded with control (Farmers practice). Data's on number of seeds in five plants, panicle length, plant height and number of tillers per square meter were also recorded and found significantly higher in laser leveling with zero tillage and $100 \%$ previous crop residue retained treatment and lowest in control (Table 1). This could be attributed to laser land leveling which may have helped in equal distribution of salt on the upper soil crust and moisture was retained in residue mulching which helps in lesser evaporation from the soil surface and leads to favorable condition to the growth of crop. These results are in line with the finding of Jat et al., 2009 and Jat et al., 2011.

\section{Water use and water productivity}

Among eight treatment, the quantum of irrigation water applied (includes effective rainfall) was less in case of laser leveling with zero tillage and $100 \%$ previous crop residue retained treatment $(454 \mathrm{~mm})$ followed by laser leveling with zero tillage and $50 \%$ previous crop residue retained treatment $(462 \mathrm{~mm})$ but was more in case of farmers practice i.e. in control treatment $(530 \mathrm{~mm})$. The total water saving was to the extent of $14.28 \%$ in case of laser leveling with zero tillage and $100 \%$ crop residue retained treatment over control treatment (Table 2). 
Table.1 Effect of precision land leveling, zero tillage and residue on wheat growth parameters (Pooled data of three years)

\begin{tabular}{|c|c|c|c|c|c|c|}
\hline Treatments & $\begin{array}{c}\text { Grain } \\
\text { yield } \\
(\mathbf{k g} / \mathbf{h a})\end{array}$ & $\begin{array}{c}\text { Straw } \\
\text { yield (kg } \\
\mathbf{h a}^{-\mathbf{1}} \mathbf{)}\end{array}$ & $\begin{array}{c}\text { No of } \\
\text { seeds in } \\
\mathbf{5} \text { plants }\end{array}$ & $\begin{array}{c}\text { Length } \\
\text { of spike } \\
(\mathbf{c m})\end{array}$ & $\begin{array}{c}\text { Plant } \\
\text { height } \\
(\mathbf{c m}) \mathbf{a t} \\
\text { harvest }\end{array}$ & $\begin{array}{c}\text { No. of } \\
\text { tillers } \\
\text { per } \mathbf{~ m}^{\mathbf{2}}\end{array}$ \\
\hline $\mathbf{T}_{\mathbf{1}}$ & 1850 & 1955 & 232 & 6.3 & 58.7 & 320 \\
\hline $\mathbf{T}_{\mathbf{2}}$ & 2040 & 2320 & 240 & 7.5 & 66.1 & 360 \\
\hline $\mathbf{T}_{\mathbf{3}}$ & 1880 & 2100 & 223 & 6.4 & 58.8 & 327 \\
\hline $\mathbf{T}_{\mathbf{4}}$ & 1890 & 2220 & 237 & 6.9 & 59.6 & 333 \\
\hline $\mathbf{T}_{\mathbf{5}}$ & 2450 & 2756 & 278 & 7.8 & 71.5 & 431 \\
\hline $\mathbf{T}_{\mathbf{6}}$ & 2340 & 2654 & 255 & 7.6 & 70.5 & 423 \\
\hline $\mathbf{T}_{\mathbf{7}}$ & 2130 & 2365 & 240 & 7.5 & 68.2 & 329 \\
\hline $\mathbf{T}_{\mathbf{8}}$ & 2010 & 2218 & 245 & 7.5 & 66.7 & 333 \\
\hline $\mathbf{S E . m \pm}$ & 34.12 & 36.25 & 8.65 & 0.25 & 1.94 & 15.30 \\
\hline $\mathbf{C D}$ @ 5\% & 112.25 & 120.50 & 33.54 & 0.86 & 5.65 & 48.45 \\
\hline
\end{tabular}

Table.2 Effect of precision land leveling, zero tillage and residue on total quantity of irrigation applied under saline Vertisols (Pooled data of three years)

\begin{tabular}{|c|c|c|c|c|c|c|c|}
\hline Treatments & $\begin{array}{l}\text { Irrigation } \\
\text { applied } \\
\left(\mathrm{m}^{3} \mathrm{ha}^{-1}\right)\end{array}$ & $\begin{array}{l}\text { Irrigation } \\
\text { applied } \\
(\mathrm{mm})\end{array}$ & $\begin{array}{l}\text { Effective } \\
\text { Rainfall } \\
\text { during } \\
\text { cropping } \\
\text { season } \\
(\mathrm{mm})\end{array}$ & $\begin{array}{c}\text { Total } \\
\text { Irrigation } \\
\text { applied } \\
\text { (mm) }\end{array}$ & $\begin{array}{c}\text { Water } \\
\text { saving ( } \% \\
\text { over } \\
\text { control) }\end{array}$ & $\begin{array}{c}\text { Total water } \\
\text { (Irrigation + } \\
\text { rain) use } \\
\left(\mathrm{m}^{3} / \mathrm{ha}\right)\end{array}$ & $\begin{array}{c}\text { Input } \\
\text { (Irrigation + } \\
\text { rain) water } \\
\text { productivity } \\
\text { kg grain } / \mathrm{m}^{3} \\
\text { water) }\end{array}$ \\
\hline $\mathbf{T}_{1}$ & 3809 & 381 & 149 & 530 & - & 5300 & 0.35 \\
\hline $\mathbf{T}_{2}$ & 3573 & 357 & 149 & 506 & 4.47 & 5064 & 0.40 \\
\hline $\mathbf{T}_{3}$ & 3473 & 347 & 149 & 496 & 6.36 & 4964 & 0.38 \\
\hline $\mathbf{T}_{4}$ & 3568 & 357 & 149 & 506 & 4.57 & 5059 & 0.37 \\
\hline $\mathbf{T}_{5}$ & 3053 & 305 & 149 & 454 & 14.28 & 4544 & 0.54 \\
\hline $\mathrm{T}_{6}$ & 3126 & 313 & 149 & 462 & 12.89 & 4617 & 0.51 \\
\hline $\mathbf{T}_{7}$ & 3152 & 315 & 149 & 465 & 12.40 & 4643 & 0.46 \\
\hline $\mathbf{T}_{8}$ & 3128 & 312.8 & 149 & 462 & 12.85 & 4619 & 0.44 \\
\hline SE.m \pm & 56.23 & 12.25 & - & 9.65 & 0.85 & 52.12 & 0.12 \\
\hline CD@5\% & 159.25 & 32.45 & - & 25.34 & 2.15 & 160.25 & 0.35 \\
\hline
\end{tabular}


Fig.1 Initial soil moisture content at 0-15 and 15-30 cm depth for different treatments

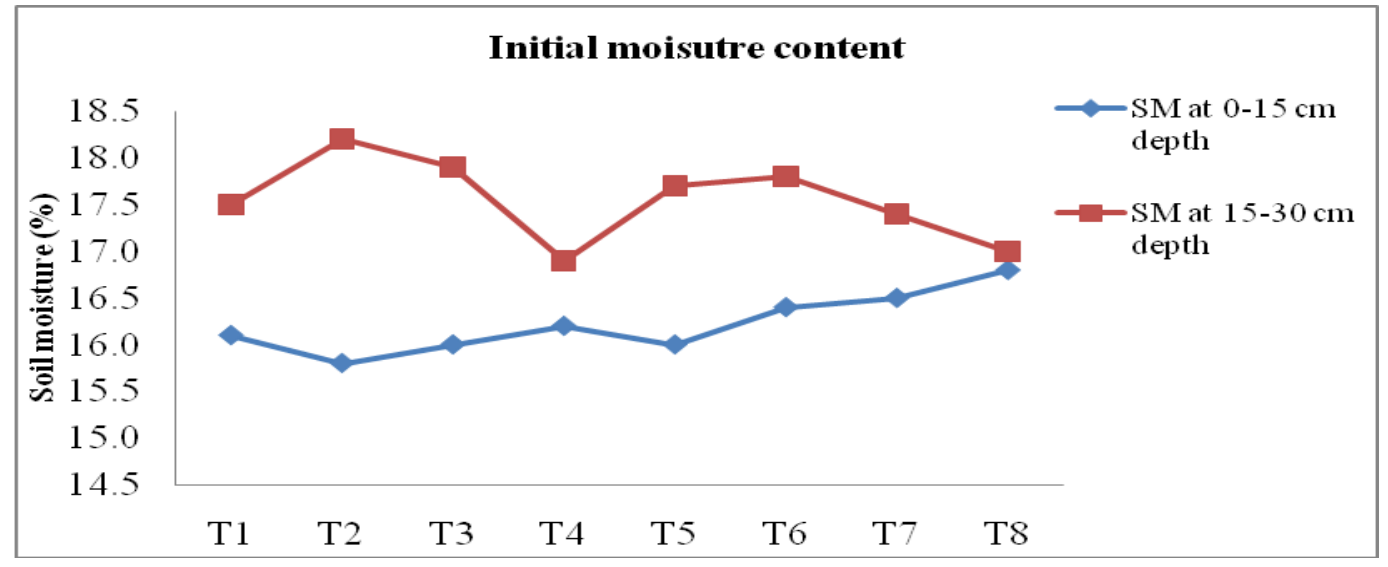

Fig.2 Effect of laser leveling and residue on soil moisture content after 90 DAS at different depths

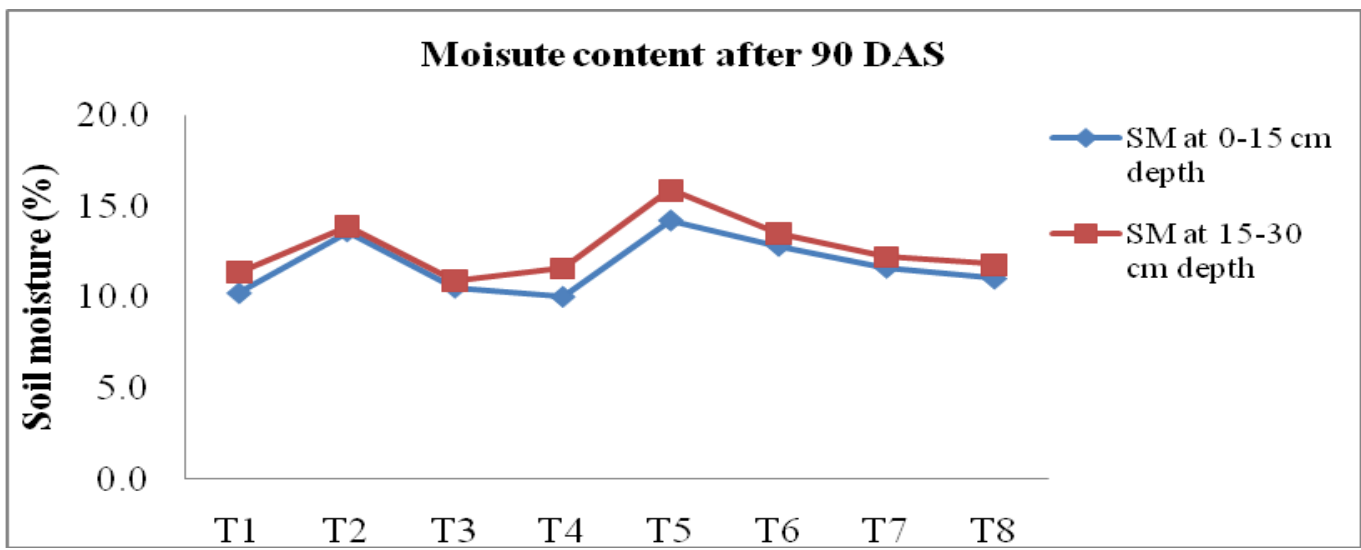

Fig.3 Effect of laser leveling and residue on soil moisture content at harvesting stage under different depths

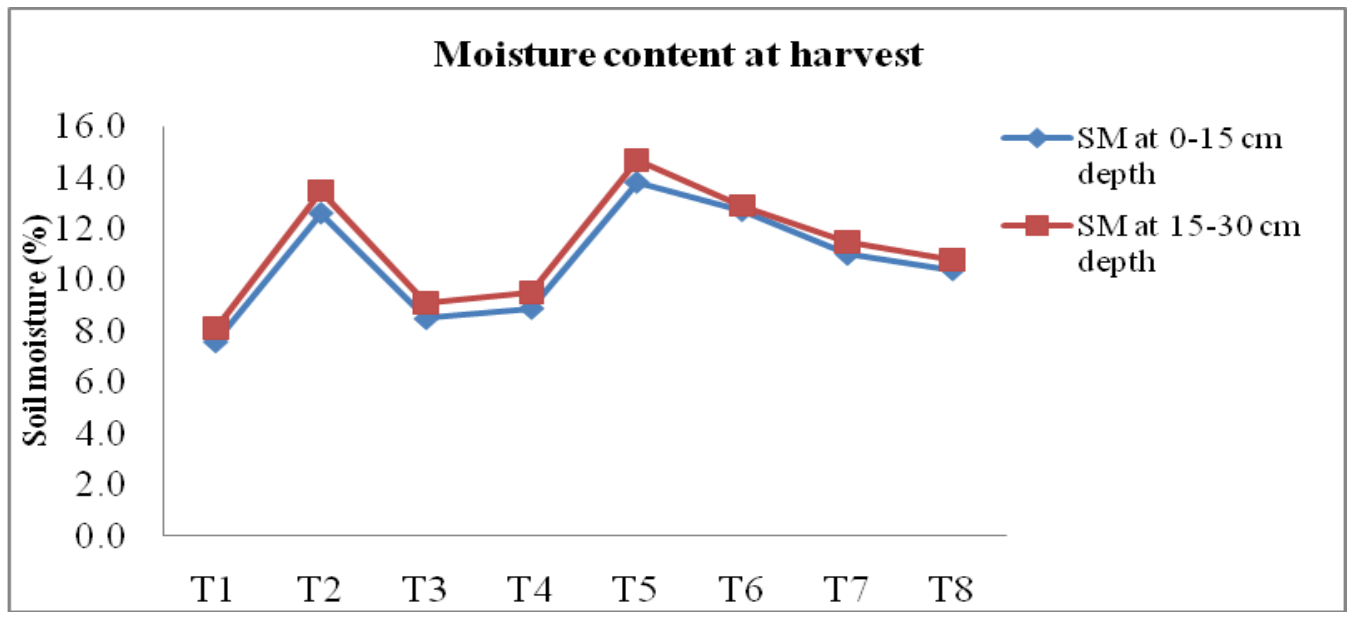


Fig.4 Effect of laser leveling, zero tillage and residue on soil on soil salinity at $0-15 \mathrm{~cm}$ depth

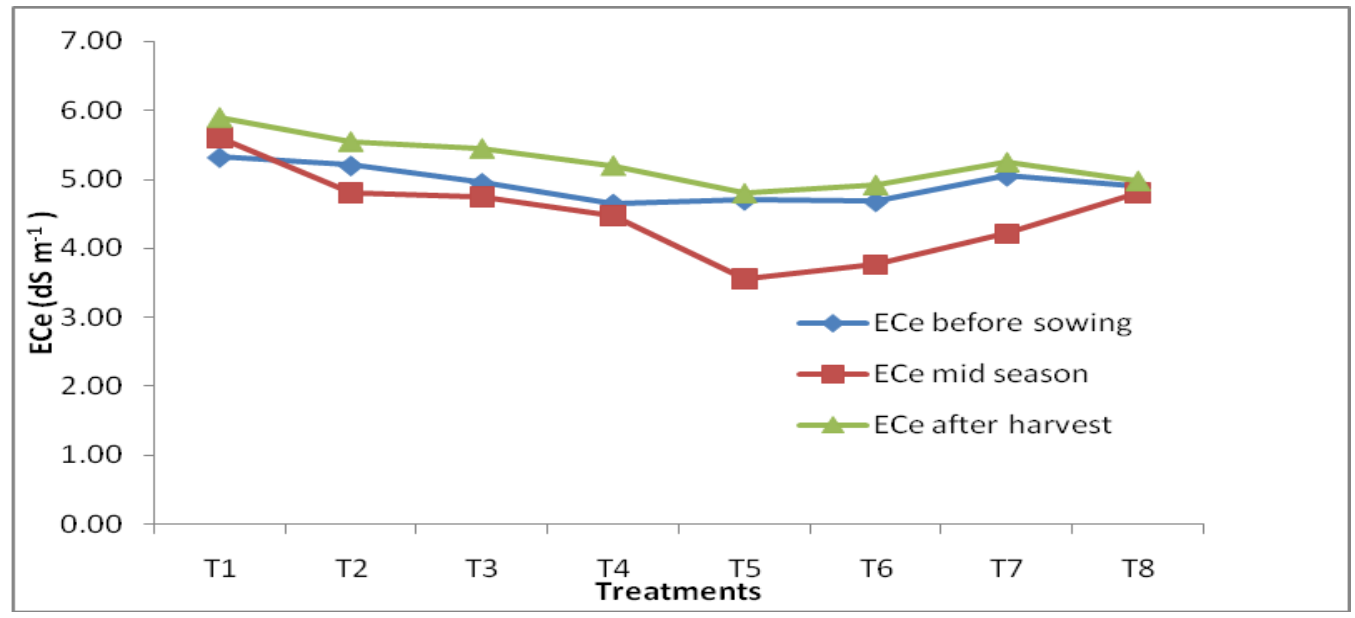

Fig.5 Effect of laser leveling, zero tillage and residue on soil on soil salinity at $15-30 \mathrm{~cm}$ depth

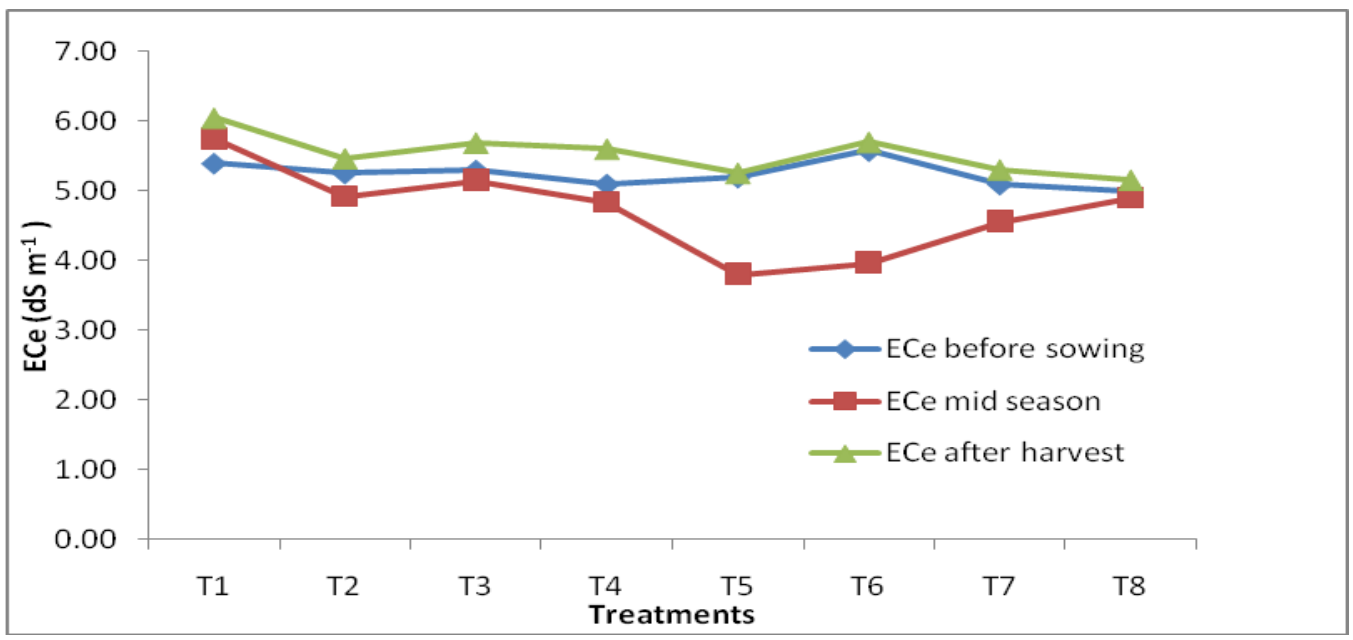

Fig.6 Effect of laser leveling, zero tillage and residue on soil on soil salinity at 30-45 cm depth

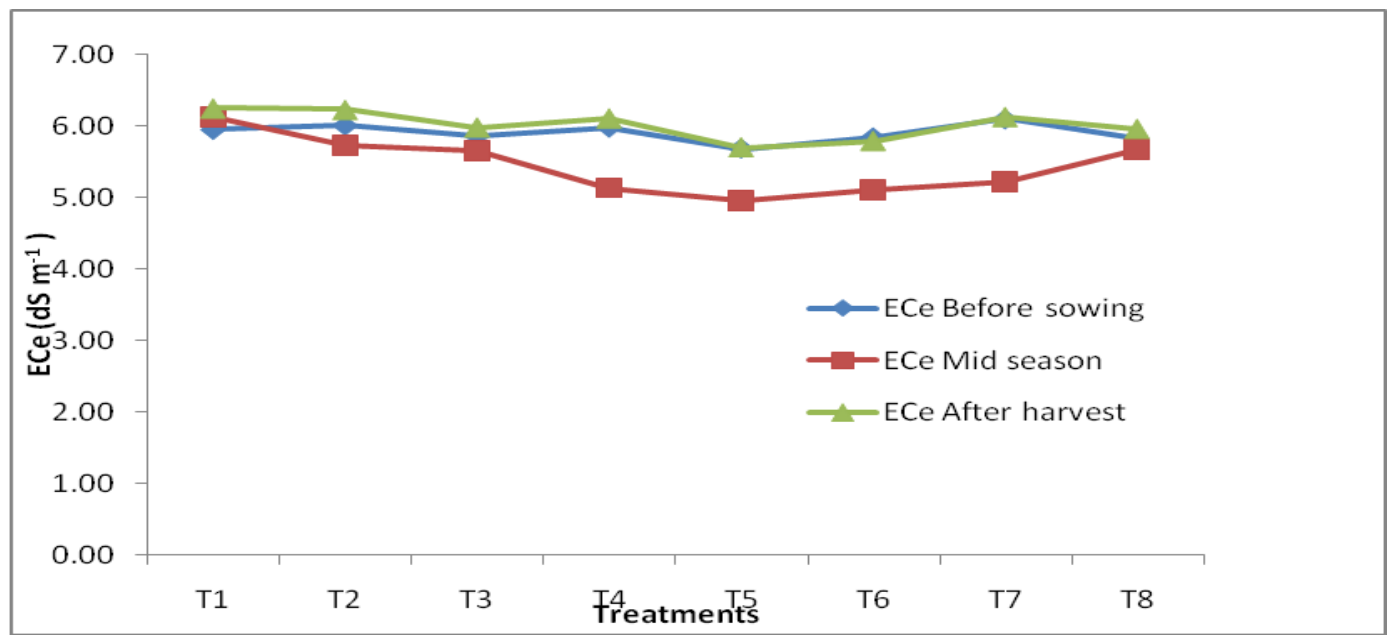


The saving in the applied irrigation was mainly because of the precision land leveling which helps in attaining the equal height of ponded water all over the corner. The water productivity for the wheat crop was calculated and it was observed that higher water productivity was recorded in case of laser leveling with zero tillage and $100 \%$ previous crop residue retained treatment $\left(0.54 \mathrm{~kg} \mathrm{~m}^{-3}\right)$ followed by laser leveling with zero tillage and $50 \%$ previous crop residue retained treatment $\left(0.51 \mathrm{~kg} \mathrm{~m}^{-3}\right)$ and least in case of control treatment $\left(0.35 \mathrm{~kg} \mathrm{~m}^{-3}\right)$. Above results are in line with the finding of Jat et al., (2011) and Shahani et al., (2016).

\section{Soil moisture}

Soil moisture content readings were recorded at initial stage, 90 DAS and at harvest. It was observed that in the initial stage of the crop more moisture was observed at $15-30 \mathrm{~cm}$ for all treatments (Fig. 1). Moisture content at 90 DAS, higher moisture was observed in both the depths (0-15 and 15-30 cm) under laser leveled with zero till and $100 \%$ crop residue retained treatment and least in control treatment i.e. farmer's practice (Fig. 2). At harvesting time the moisture content was similar as in case of 90 DAS (Fig. 3). This was mainly because of less evaporation in 100 $\%$ crop residue retention, zero tillage and laser leveling. The above results are in line with findings of Gangwar et al., (2006).

\section{Soil salinity and pH}

The soil $\mathrm{pH}$ and salinities for $0-15,15-30$ and $30-45 \mathrm{~cm}$ depths at before sowing, 90 DAS and after harvest were recorded. The soil $\mathrm{pH}$ and ECe of the blocks varied initially between $8.29-8.55$ and $4.68-5.32 \mathrm{dS} \mathrm{m}^{-1}$ at $0-15 \mathrm{~cm}$, $8.10-8.23$ and $5.0-5.58 \mathrm{dS} \mathrm{m}^{-1}$ at $15-30 \mathrm{~cm}$ and $8.25-8.45$ and $5.68-6.10 \mathrm{dS} \mathrm{m}^{-1}$ at 30$45 \mathrm{~cm}$ depth respectively. Before sowing, soil salinity was slightly higher at control treatment $\left(5.32 \mathrm{dS} \mathrm{m}^{-1}\right)$ at $0-15 \mathrm{~cm}^{\text {depth }}$ followed by treatment $\mathrm{T}_{2}\left(5.20 \mathrm{dS} \mathrm{m} \mathrm{m}^{-1}\right)$ and least in case of $\mathrm{T}_{4}\left(4.65 \mathrm{dS} \mathrm{m} \mathrm{m}^{-1}\right)$. The salinity during 90 DAS or mid-season of the crop, the study did not find the salinity on the $0-15 \mathrm{~cm}$ depth of the soil in all the laser leveling treatments with $100 \%$ and $50 \%$ crop residue retained treatments (3.55 and $3.76 \mathrm{dS} \mathrm{m}^{-1}$ ) respectively. During this season the soil salinity for different treatments was less compared to before sowing and after harvest because of leaching of salts. Decreased soil salinity of $100 \%$ crop residue retained treatments was mainly because of residue retention on the surface which helped in reducing the evaporation losses. Due to reduction in evaporation losses and maintaining of the soil moisture, the salinity built-up was less in the rooting depth. The above results are in line with findings of Chatrath et al., (2007). After harvest, the soil salinity was observed that in all the treatments the soil salinity was increased slightly. This is because of no irrigation to the crop at harvesting stage which intern leads to higher evaporation and the salt moved towards the top soil layer. However, comparatively higher soil salinity increase was observed at control treatment $\left(5.90 \mathrm{dS} \mathrm{m} \mathrm{m}^{-1}\right)$ i.e. in farmer's practice because of no residue on the land surface and uneven land surface at $0-15 \mathrm{~cm}$ depth. Least soil salinity increase was observed in laser leveling with zero tillage and $100 \%$ crop residue retained treatment $\left(\mathrm{T}_{5}\right)$ (Fig. 4). Similar trend were observed in case of 15-30 and 30-45 cm soil depth (Fig. 5 and $6)$.

\section{Soil organic carbon (OC)}

The data on soil OC in surface $(0-15 \mathrm{~cm})$ and subsurface $(15-30 \mathrm{~cm})$ varied from 0.53 to 0.62 and 0.42 to 0.54 per cent with an average of 0.56 and 0.48 per cent respectively as compared to initial data (0.4 to $0.5 \%)$. However, surface soil OC content was found 
to be medium (0.5-0.75 per cent) and subsurface was in low $(<0.5$ per cent $)$ category as per soil fertility ratings (Tandon, 2005). After harvest of the third year wheat crop, slightly higher organic carbon $(0.62$ per cent) was observed in $100 \%$ crop residue (wheat straw) retained treatment as compared to initial ( 0.5 per cent). This may be due to decaying of previous crop residue, addition of root biomass, addition of other organic manure etc. Present observations are in line with the findings of Kumar et al., 2007 who reported medium to high OC content of these soils and attributed to in-situ incorporation of paddy stubbles and addition of organic manures in these soils at A.R.S Gangavathi.

RCT's viz., precision land leveling, zero tillage and residue retention have effect on soil moisture, soil salinity, water productivity and yield of wheat crop. It was found that laser land leveling and 100\% residue retained treatment was found better with respect to moisture retention and water productivity which was on par with $50 \%$ crop residue retention. Water productivity and saving in the applied water was also higher in laser leveling with zero tillage and $100 \%$ previous crop residue retained treatment compared to other treatments. In saline soils, higher yield of wheat and water saving could be achieved through laser land leveling and $100 \%$ residue retained. It was advisable that in case $100 \%$ residue retention is not possible at least $50 \%$ previous crop residue retention under zero tillage is also a better or alternate option.

\section{References}

Chatrath, B., Mishra, B., Ortiz Ferrara, G., Singh, S. K and Joshi, A. K. 2007. Challenges to wheat production in South Asia. Euphytica., 157(3): 447456.

Choudhary, M.A., Gill, M. A., Kahlown, A and Hobbs, P. R. 2002. Evaluation of resource conservation technologies in rice-wheat system of Pakistan. In: Proceedings of the international workshop on developing an action program for farm level impact in ricewheat system of Indo-Gangetic plains. New Delhi, India, 25-27 September 2000, Rice-Wheat Consortium Paper Series 14. Rice-Wheat Con- sortium for the Indo-Gangetic Plains. pp. 148-155.

Corey, G and Clyma, W. 1973. Irrigation practices for traditional and precision leveled field in Pakistan. Proceedings of optimum use of water in agriculture. Scientific Paper No. 16.

Doran, M., Frankenberger, W.T.J and Smith, L. H. 1987. The influence of organic matter on soil aggregation and water infiltration. J. Prod. Agri., 2: 290-299.

Erenstein, O., Farooq, U., Malik, R. K and Sharif, M. 2007. Adoption and impacts of zero- tillage as a resource conserving technology in the irrigated plains of South Asia. In: Comprehensive Assessment of Water Management in Agriculture. Research Report 19, Colombo, Sri Lanka. pp. 25-30.

Gangwar, K. S., Singh. K. K., Sharma. S. K and Tomar, O. K. 2006. Alternate tillage and crop residue management in wheat after rice in sandy loam soils of Indo-Gangetic plains. Soil \& Tillage Research, 88: 242-252.

Gill, M. S., Pal, S. S and Ahlawat, I. P. S. 2008. Approaches for sustainability of rice (Oziza sativa) - wheat (Triticum aestivum) cropping system in IndoGangetic Plains of India- A review. Indian Journal of Agronomy, 53(2): 8196.

Gupta, R. K and Sayre, K. 2007. Conservation agriculture in South Asia. J. Agri. Sciences Cambridge, 145:207214.

Gupta, R. K and Seth, A. 2007. A review of resource conserving technologies for 
sustainable management of the ricewheat cropping systems of the IndoGangetic plains. Crop Protection 26:436-447.

Gupta, R. K., Hobbs, P. R., Jiaguo, J and Ladha, J. K. 2003. Sustainability of post-green revolution agriculture. In: Ladha, J.K., et al., (Eds.), Improving the Productivity and Sustainability of RiceWheat Systems: Issues and Impacts. ASA Spec. Publ. 65, ASA, CSSA, and SSSA, Madison, WI. pp. 1-25.

Jat, M. L and Parvesh Chandna. 2004. Precision Land Leveling -Laser Land Leveling System, Rice Wheat Information Sheet (RWIS 48, June edition), Rice Wheat Consortium, New Delhi.

Jat, M. L., Chandana, P., Sharma, S. K., Gill, M. A. and Gupta, R. K. 2006a. Laser Land Leveling: A Precursor Technology for Resource Conservation. Rice-Wheat Consortium Technical Bulletin Series 7. Rice-Wheat Consortium for the IndoGangetic Plains, New Delhi, India. pp. 48.

Jat, M. L., Gathala, M. K., Ladha, J. K., Saharawat, Y.S., Jat. A. S., Vipin Kumar., Sharma. S. K., V. Kumar and Raj Gupta. 2009. Evaluation of precision land leveling and double zerotill systems in the rice-wheat rotation: Water use, productivity, profitability and soil physical properties. Soil and Tillage Research, 105: 112-121.

Jat, M. L., Pal, S. S., Subba Rao, A. V. M and Sharma, S. K. 2003. Improving resource use efficiency in wheat through laser land leveling in an ustochrept of IndoGangetic plain. In: National Seminar on Developments in Soil Science, 68th Annual Convention of the Indian Society of Soil Science, November 4-8, CSAUAT, Kanpur (UP). pp. 55-60.

Jat. M. L., Raj Gupta, Y. S. Saharawat and Raj Khosla. 2011. Layering Precision
Land Leveling and Furrow Irrigated Raised Bed Planting: Productivity and Input Use Efficiency of Irrigated Bread Wheat in Indo-Gangetic Plains. American J. of Plant Scie. 2: 578-588.

Kahlown, M.A., Raoof, A and Hanif, M. 2000. Rice yield as affected by plant densities. Mona Experimental Project Bhalwal, Report No. 238.

Khan, B. M. 1986. Overview of water management in Pakistan. Proceedings of Regional seminar for SAARC member countries on farm water management. Govt. of Pakistan. pp. 8.

Khattak, J. K., Larsen, K. E., Rashid, A., Khattak, R. A and Khan, S.U. 1981. Effect of land leveling and irrigation on wheat yield. Journal of AMA. 12: 11-14.

Kirkby, C. A. 1999. Survey of content rice stubble management practices for identification of research needs and future policy. RIRDC project no. CSL$5 \mathrm{~A}$.

Kumar, H. K. 2007, Chemistry and fertility zinc selected paddy soils of Tungabhadra command. M. Sc. (Agri) Thesis, Uni. Agril. Sci., Dharwad. Pp. 64.

Malik, R. K., Yadav, A., Singh, S., Malik, R. S., Balyan, R. S., Banga, R.S., Sardana, P. K., Jaipal, S., Hobbs, P.R., Gill, G., Singh, S., Gupta, R.K and Bellinder, R. 2002. Herbicide Resistance Management and Evolution of Zero Tillage: A Success Story. Research Bulletin. CCS Haryana Agricultural University, Hisar, India. pp. 43.

Prasad, R., Gangaiah, B and Aipe, K.C. 1999. Effect of crop residue management in a rice wheat cropping system on growth and yield of crops and on soil fertility. Exp. L Agri., 35: 427-435.

Rickman, J. F. 2002. Manual for laser land leveling, Rice-wheat Consortium Technical Bulletin Series 5. New Delhi- 
12, India: Rice-wheat Consortium for the Indo-Gangetic Plains. Pp. 24.

Rickman, J. F., Bunna, S., Sinath, P. 1998. Agricultural Engineering. In: Program Report for 1998, International Rice Research Institute, Manila, Philippines. pp. 142.

Sattar, A., Khan. F.H and Tahir, A.R. 2003. Impact of precision land leveling on water saving and drainage requirement. J. AMA. 34: 39-41.U.S. Department of Agriculture. 1977. Research progress and needs conservation tillage. USDAARS, North Center Region, ARS-NS: 57.

Shahani Wajid Ali., Kaiwen Feng and Aslam Memon. 2016. Impact of laser leveling technology on water use efficiency and crop productivity in the cotton -wheat cropping system in Sindh. Inter. J. of research- Granthaalayah, 4(2): 220231.

Tandon, H. L. S. 2005. Methods of analysis of soils, plants, waters, fertilizers and organic manures. Fertilizer development and consultation organisation, New Delhi. India. pp. 140.

Vivak Kumar., Yashpal. S. S., Mahesh, K. G., Jat, A. S., Sanja, K. S., Neelam Chaudhary and Jat, M. L. 2013. Effect of different tillage and seeding methods on energy use efficiency and productivity of wheat in the IndoGangetic Plains. Field Crop Research, 142: $1-8$.

\section{How to cite this article:}

Rajkumar, R.H., A.T. Dandekar, S.R. Anand, J. Vishwantha, A.V. Karegoudar, P.H. Kuchnur and Yogesh Kumar Singh. 2018. Effect of Precision Land Levelling, Zero Tillage and Residue Management on Yield and Water Productivity of Wheat (Triticum aertivum L.) under Saline Vertisols of Tungabhadra Project Command. Int.J.Curr.Microbiol.App.Sci. 7(10): 2925-2935. doi: https://doi.org/10.20546/ijcmas.2018.710.340 